\title{
Failure to Deliver
}

National Cancer Institute

\section{Source}

National Cancer Institute. Failure to Deliver. NCI Thesaurus. Code C63186.

Failure (=complete nonperformance) with regard to the intended function of delivery. 